\title{
Cultural competence: reply to Taylor et al.
}

\author{
Nicholas Heitkamp ${ }^{1} \cdot$ Richard B. Gunderman ${ }^{1}$ \\ Received: 20 May 2021 / Revised: 20 May 2021 / Accepted: 1 June 2021 / Published online: 30 June 2021 \\ (C) The Author(s), under exclusive licence to Springer-Verlag GmbH Germany, part of Springer Nature 2021
}

Dear Editors,

We thank Drs. Taylor, Ayyala, Coley and HernanzSchulman for their thoughtful letter [1], and we are delighted that our article [2] has stimulated such reflection and discussion. We second their call for cultural humility and note that just as there is no such thing as the outlook from nowhere, no one can offer a perspective from everywhere. We chose to focus on Hispanic culture because of its distinctive and growing demographic significance, but there are more or less generalizable lessons that can be gleaned from the study of any culture.

Good patient care is a scientific and clinical endeavor but no less a cultural one. By doing our best to understand the culture of each patient and family, we enhance our prospects for providing excellent care and finding more fulfillment in our work. Going forward, we hope that the topic of culture will continue to receive more attention in the education of pediatric radiologists, professional meeting programs, and the pages of our journals.

\section{Declarations}

Conflicts of interest None

\section{References}

1. Taylor GA, Ayyala RS, Coley BD, Hernanz-Schulman M (2021) Cultural competence in pediatric radiology: Hispanic culture. Pediatr Radiol. https://doi.org/10.1007/s00247-021-05113-9

2. Hietkamp N, Gunderman RB (2021) Cultural competence in pediatric radiology: Hispanic culture. Pediatr Radiol 51:11-13

Publisher's note Springer Nature remains neutral with regard to jurisdictional claims in published maps and institutional affiliations.

Richard B. Gunderman

rbgunder@iu.edu

1 Department of Radiology, Indiana University,

702 North Barnhill Drive, Room 1053, Indianapolis, IN 46202, USA 